\title{
THE MACROMOLECULAR COMPONENT OF THE PALM-LEAF-LIKE CRYSTALS IN DRIED SAMPLES OF RABBIT SEMINAL PLASMA
}

\author{
J. E. KIHLSTRÖM \\ Institute of Zoophysiology, Uppsala, Sweden
}

(Received 26th September 1970)

\begin{abstract}
Summary. The appearance of palm-leaf-like crystals in air-dried preparations of seminal plasma has been studied before and after incubation of rabbit seminal plasma with different enzymes. Proteolytic enzymes, and, in some experiments, lysozyme, bring about changes preventing the formation of these crystals. The shape of the crystals seems, therefore, to be determined mainly by proteins. In some cases, glucosamine-containing polysaccharides may contribute to the determination of this shape.
\end{abstract}

\section{INTRODUCTION}

As early as 1921, palm-leaf-like crystals, resembling those formed in human cervical mucus, were observed in dried preparations of whole semen from cattle, horses and rabbits (Yamane, 1921). Such crystals are also occasionally seen in semen from boars (Bane, personal communication). In cattle and rabbits, the crystals are more regularly found after removal of the spermatozoa and crystals have also been shown to occur in the process of drying human seminal plasma (Kihlström \& Fjellström, 1969a).

The palm-leaf-like crystals found in preparations of human cervical mucus are composed mainly of sodium chloride and contain small amounts of organic matter (Rydberg, 1948; Zondek, 1957; MacDonald, 1963), their shape being determined by a macromolecular matrix (Rydberg, 1948; Sokolovskaya, 1965). The present paper gives some information about the composition of a corresponding matrix in crystals from seminal fluid, studied by means of enzymatic digestion.

\section{MATERIALS AND METHODS}

The buffers used were prepared from 0.2 M-trishydroxymethylaminomethane maleate and $0.2 \mathrm{~m}-\mathrm{KOH}$. Commercial preparations of enzymes (Table 1) were dissolved in buffer solutions $(5 \% \mathrm{w} / \mathrm{v})$ having the appropriate $\mathrm{pH}$. With the exception of di-isopropylfluorophosphate (DPFP) and taurocholate, the chemicals used as activators and inhibitors (Table 2) were of analytical grade. All solutions were made up with water distilled twice in quartz apparatus.

Semen was obtained from thirty-two bucks of mixed breeds by means of an 
TABLE 1

ORIGIN AND ACTIVITY OF ENZYME PREPARATIONS

\begin{tabular}{|c|c|c|}
\hline Enzyme & $\begin{array}{c}\text { Origin } \\
\text { (if indicated) }\end{array}$ & Activity \\
\hline $\begin{array}{l}\alpha \text {-chymotrypsin, type II (Sigma Ltd) } \\
\text { Trypsin (Merck Ltd) } \\
\text { Pepsin, N.F. XI (Kebo Ltd) }\end{array}$ & Bovine pancreas & $\begin{array}{l}42 \text { units/mg } \\
20 \text { Fuld-Gross units/mg } \\
\text { Digest } 3000 \text { times its weight of } \\
\text { freshly coagulated and disinte- } \\
\text { grated egg albumin in } 2 \frac{1}{2} \mathrm{hr} \text { at } \\
52^{\circ} \mathrm{C} \text { in water acidified with } \\
\mathrm{HCl}\end{array}$ \\
\hline Lecinthinase C, type I (Sigma, Ltd) & Cl. welchii & $\begin{array}{l}0.5 \text { to } 2.0 \mu \mathrm{mol} \text { organic phos- } \\
\text { phate liberated from lecithine/ } \\
\text { min/mg at }+37^{\circ} \mathrm{C} \text { and } \mathrm{pH} 7.3\end{array}$ \\
\hline Lipase, crude, type II (Sigma Ltd) & Hog pancreas & $\begin{array}{l}19 \text { equivalents of acid liberated } \\
\text { from triacetin } / \mathrm{hr} / \mathrm{mg} \text { at } 37^{\circ} \mathrm{C} \\
\text { and } \mathrm{pH} 7 \cdot 4\end{array}$ \\
\hline$\alpha$-amylase (Calbiochem Ltd) & Bacteria & 5 SKB units/mg \\
\hline Lysozyme, Grade I (Sigma Ltd) & Egg white & $3.5 \times 10^{4}$ units $/ \mathrm{mg}$ \\
\hline Neuraminidase B grade (Calbiochem Ltd) & Vibrio cholerae & 500 units $/ \mathrm{ml}$ \\
\hline
\end{tabular}

TABLE 2

THE OCCURRENCE OF ARBORACEOUS GRYSTALS UPON DRYING OF SEMINAL PLASMA PREVIOUSLY TREATED WITH ENZYMES WITH AND WITHOUT THE ADDITION OF DIFFERENT INHIBITORS*

\begin{tabular}{|c|c|c|c|c|c|c|}
\hline \multirow{2}{*}{ Enzyme used } & \multirow{2}{*}{$p H$} & \multirow{2}{*}{$\begin{array}{l}\text { Final concentration of } \\
\text { activator }\end{array}$} & \multirow{2}{*}{$\begin{array}{l}\text { Final concentration of } \\
\text { inhibitor }\end{array}$} & \multirow{2}{*}{$\begin{array}{l}\text { Total no. } \\
\text { of } \\
\text { experiments }\end{array}$} & \multicolumn{2}{|c|}{$\begin{array}{l}\text { No. of experiments } \\
\text { after the enzymatic } \\
\text { treatment }\end{array}$} \\
\hline & & & & & $\begin{array}{c}\text { With } \\
\text { crystals }\end{array}$ & $\begin{array}{l}\text { Without } \\
\text { crystals }\end{array}$ \\
\hline Chymotrypsin & $7 \cdot 8$ & $5 \times 10^{-2} \mathrm{M}-\mathrm{CaCl}_{2}$ & $10^{-3}{ }_{m-D P F P}+$ & $\begin{array}{l}15 \\
10\end{array}$ & $\begin{array}{r}3 \\
10\end{array}$ & $\begin{array}{r}12 \\
0\end{array}$ \\
\hline Pepsin & $5 \cdot 2$ & - & - & 9 & 0 & 9 \\
\hline Trypsin & $7 \cdot 4$ & $5 \times 10^{-2} \mathrm{M}-\mathrm{CaCl}_{2}$ & $10^{-3} x-\overline{D P F P}$ & $\begin{array}{l}19 \\
12\end{array}$ & $\begin{array}{r}3 \\
12\end{array}$ & $\begin{array}{r}16 \\
0\end{array}$ \\
\hline Lecithinase & $7 \cdot 3$ & $10^{-2} \mathrm{M}-\mathrm{CaCl}_{2}$ & - & 7 & 7 & 0 \\
\hline Lipase & $7 \cdot 4$ & $10^{-2} \mathrm{M}$-taurocholate & $10^{-3}{ }_{M-D P F P}$ & $\begin{array}{l}21 \\
13\end{array}$ & $\begin{array}{r}2 \\
13\end{array}$ & $\begin{array}{r}19 \\
0\end{array}$ \\
\hline Amylase & $7 \cdot 0$ & $2 \times 10^{-2} \mathrm{M}-\mathrm{KCl}$ & $\begin{array}{l}10^{-3} \mathrm{M}-\overline{\mathrm{PFP}} \\
10^{-3} \mathrm{M} \text {-EDTA } \\
10^{-3} \text { M-sodium oxalate }\end{array}$ & $\begin{array}{r}15 \\
9 \\
3 \\
3\end{array}$ & $\begin{array}{l}1 \\
9 \\
0 \\
0\end{array}$ & $\begin{array}{r}14 \\
0 \\
3 \\
3\end{array}$ \\
\hline Lysozyme & $6 \cdot 2$ & - & $\begin{array}{l}10^{-3} \mathrm{M}-\overline{\mathrm{PFP}} \\
10^{-2} \mathrm{M} \text {-iodoacetamide } \\
1 \% \%^{\circ} \text { ovomucoid } \\
10^{-3} \text { M-laurylsulphate }\end{array}$ & $\begin{array}{r}22 \\
11 \\
6 \\
7 \\
13\end{array}$ & $\begin{array}{r}15 \\
6 \\
1 \\
4 \\
13\end{array}$ & $\begin{array}{l}7 \\
5 \\
5 \\
3 \\
0\end{array}$ \\
\hline Neuraminidase & $5 \cdot 2$ & $10^{-3} \mathrm{M}-\mathrm{MgCl}_{2}$ & - & 16 & 16 & 0 \\
\hline
\end{tabular}

* In all experiments, crystals were observed in the untreated parts of the samples.

$\uparrow$ DPFP = di-isopropylfluorophosphate. 
artificial vagina. Immediately after the collection, the ejaculates were freed from spermatozoa by centrifuging for $10 \mathrm{~min}$ at $975 \mathrm{~g}$. A small drop of seminal plasma from each ejaculate on a clean glass slide was dried in air at a temperature of 21 to $23^{\circ} \mathrm{C}$ and the occurrence and type of crystals in the preparation were registered. Five parts of seminal plasma were thoroughly mixed with one part of the stock-solution of the particular enzyme and the mixture incubated at $37^{\circ} \mathrm{C}$ for $240 \mathrm{~min}$. Two control-solutions (five parts of seminal plasma plus one part of buffer and one part of the enzyme solution plus five parts of buffer, respectively) were incubated simultaneously. After incubation, a drop of each solution was dried as described above and the occurrence and type of crystals again observed.

With only one exception in more than 200 ejaculates, the crystal patterns were identical, no matter whether the preparations were obtained from seminal plasma or from the solution mentioned above containing five parts of seminal plasma and one part of buffer. Moreover, arboraceous crystals were never observed after incubation of one part of the enzyme-solution mixed with five parts of buffer, indicating that, in the concentrations used, the enzymes themselves do not give rise to any such crystals. Changes in the crystal patterns occurring during incubation of five parts of seminal plasma with one part of an enzyme-buffer-solution were presumably caused by an enzymatic digestion of molecules necessary for the formation of the crystals.

\section{RESULTS}

The two types of crystals observed in rabbit seminal plasma (Kihlström \& Fjellström, 1969a) were both affected in the same way during the enzymatic treatment. As seen from Table 2, incubations with pepsin, trypsin, chymotrypsin, pancreatic lipase, amylase and lysozyme prevent the formation of the crystals. One or more components of these enzyme preparations must therefore digest the molecules necessary for formation of the arboraceous crystals.

Organo-phosphorous compounds, such as DPFP, strongly inhibit trypsin and chymotrypsin (Jansen, Nutting, Jang \& Balls, 1949). After addition of DPFP to the solution of these enzymes, the latter lose their capacity to prevent the formation of the crystals (Table 2). Consequently, there are strong reasons to believe that the matrix determining the forms of the crystals contains a proteinaceous component.

The preparation of pancreatic lipase used is also said to contain trypsin. The addition of DPFP causes the preparation to lose its effect upon the formation of the crystals (Table 2). As this protease inhibitor stabilizes pancreatic lipase (Desnuelle, Constantin \& Sarda, 1956), these results (Table 2) indicate that the active components of the lipase preparation also include trypsin and/or chymotrypsin.

Preparations of bacterial amylases have been shown to be contaminated by traces of proteases even after repeated crystallizations (Stein \& Fischer, 1958). After the addition of DPFP, the preparation loses its ability to prevent the formation of the crystals (Table 2). However, the addition of compounds known to inhibit $\alpha$-amylase, such as EDTA (Yamamoto, 1956; Muus, Brockett \& Conelly, 
1956) and oxalate (Yamamoto, 1956) does not abolish this ability (Table 2). Proteolytic enzymes contaminating the preparation of amylase are therefore presumed to be responsible for the prevention of the formation of the arboraceous crystals.

Lysozyme prevents the formation of arboraceous crystals in some experiments (Table 2). This ability persists after the addition of DPFP, ovomucoid (Table 2), both potent inhibitors of trypsin and chymotrypsin (Jansen et al., 1949; Lineweaver \& Murray, 1947), and iodoacetamide (Table 2), indicating that the activity does not depend upon contaminating proteases, sensitive to sulphhydryl-blocking agents.

However, after the addition of laurylsulphate, a specific inhibitor of lysozyme (Meyer, Prudden, Lehman \& Steinberg, 1947), no effects upon the crystal pattern can be observed. It seems likely that, at least in some cases, lysozyme is able to digest those molecules which are necessary for the formation of the crystals. These cases were neither restricted to certain individuals, nor to any special type of crystals.

The results obtained indicate that the shape of the crystals is mainly determined by proteins. At least in some cases, polysaccharides containing $\beta$-glucosamine may contribute significantly to the determination of this structure.

\section{DISCUSSION}

The tris-maleate-KOH-buffer was used in order to avoid the addition of $\mathrm{Na}^{+}$ and $\mathrm{Cl}^{-}$to the seminal plasma, as the type of crystal varies with the concentrations of these ions (Kihlström \& Fjellström, 1969b).

Ribonucleic acids might be involved in the formation of the crystal pattern but in bulls, at least, the amount of ribose-containing material in the seminal plasma seems to be small and variable (Bhargava, Bishop \& Work, 1959). For this reason, the effect of $\mathrm{RN}$-ase was only tested in a few preliminary experiments, all of which indicated that this enzyme does not influence the crystal pattern.

Seminal plasma from rabbits is known to contain hyaluronidase (Hechter \& Hadidian, 1947) and it, therefore, seems unlikely that hyaluronic acid would be involved in the formation of the crystals. Preliminary experiments with hyaluronidase confirmed that there was no effect on crystallization.

In female secretions, the shape of the palm-leaf-like crystals is said to depend upon the presence of a proteinaceous matrix, most likely a mucoid (Rydberg, 1948; Sokolovskaya, 1965). It appears that this may also be the case with the analogous crystals in the seminal plasma.

\section{ACKNOWLEDGMENTS}

This work was supported by a grant from the Swedish Natural Science Research Council. For stimulating discussions, I thank the Head of the Institute, Professor P. E. Lindahl. Skilful technical assistance by Mrs I. Nilsson, Mrs K. Järnebrand and Miss E-B. Norlin is gratefully acknowledged. 


\section{REFERENCES}

Bhargava, P. M., Bishop, M. W. H. \& Work, T. S. (1959) The chemical composition of bull semen with special reference to nucleic acids, free nucleotides and free amino acids. Biochem. 7.73 , 242.

Desnuelle, P., Constantin, M. J. \& Sarda, L. (1956) Action de certains dérivés organophosphoriques sur la lipase et "l'estérase" du pancréas. Bull. Soc. Chim. biol. 38, 625.

Hechter, O. \& Hadidian, Z. (1947) Hyaluronidase activity of spermatozoa. Endocrinology, 41, 204.

Jansen, E. F., Nutting, M. D. F., Jang, R. \& Balls, A. K. (1949) Inhibition of the proteinase and esterase activities of trypsin and chymotrypsin by di-isopropylfluorophosphate: crystallization of inhibited chymotrypsin. F. biol. Chem. 179, 189.

KinLSTRöM, J. E. \& FJELLSTröm, D. (1969a) Cyclical variations in arboraceous crystal pattern of airdried seminal fluid. Acta obstet. gynec. scand. 48, 147.

Kinlström, J. E. \& FJELLSTröm, D. (1969b) An arboraceous crystal pattern in air-dried seminal fluid. 7. Reprod. Fert. 19, 375.

Lineweaver, H. \& MuRray, C. W. (1947) Identification of the trypsin inhibitor of egg white with ovomucoid. 7. biol. Chem. 171, 565.

MacDonald, R. R. (1963) Cervical mucus and the management of abortion. F. Obstet. Gynaec. Br. Commonw. 70, 580.

Meyer, K., Prudden, J. F., Lehman, W. L. \& Steinberg, A. (1947) Lysozyme content of the stomach and its possible relationship to peptic ulcer. Proc. Soc. exp. Biol. Med. 65, 220.

Muus, J., Brockett, F. P. \& Conelly, C. C. (1956) The effect of various ions on the stability of crystalline salivary amylase in solution. Archs Biochem. Biophys. 65, 268.

Rydrerg, E. (1948) Observations on the crystallization of the cervical mucus. Acta obstet. gynec. scand. $28,172$.

Sokolovskaya, I. I. (1965) Cinemicrographic studies and artificial models of cow cervical secretion. 5th Int. Congr. Anim. Reprod. A.I. Trento, 6, 35.

STEIN, E. A. \& FischeR, R. H. (1958) The resistance of $\alpha$-amylase towards proteolytic attack. 7. biol. Chem. 232, 867.

Yамамото T. (1956) Studies on the bacterial $\alpha$-amylase, especially in regard to the role of calcium contained. Bull. agric. Chem. Soc. Japan, 20, 188.

YAMANe, J. (1921) Studien über die physikalischen und chemische Beschaffenheit des Pferdespermas mit besonderer Berücksichtigung der Physiologie der Spermatozoen. 7. Coll. Agric., Hokkaido imp. Univ. 19, 161.

Zondex, B. (1957) Cervical mucus arborization as an aid in diagnosis. Prog. Gynec. 3, 86. 